\title{
NAVIGATING IN TROUBLED WATERS: SOUTH AMERICAN EXPORTS OF FOOD AND AGRICULTURAL PRODUCTS, 1900-1950*
}

\author{
VICENTE PINILLA \\ Universidad de Zaragoza ${ }^{a}$ \\ GEMA APARICIO \\ Independent Scholar ${ }^{\mathrm{b}}$
}

\begin{abstract}
The objective of this article is to offer empirical evidence regarding the behaviour of the exports and relative prices of agricultural and food products from South America between 1900 and 1950. These were years of intense turbulence, which profoundly affected the countries of the region, generating a deep pessimism concerning the potentiality of the export-led development model. This study offers a new quantitative base to analyse the evolution of exports of agrifood products from South America between 1900 and 1938. The paper also offers a series for the evolution of the terms of trade in the region which takes into account in its construction, for the first time, the relative weights of South American exports of the distinct agricultural products.
\end{abstract}

Keywords: Latin American economic history, international agrifood trade, great depression, terms of trade

JEL codes: F14, N56, N70, N76, Q17

* Received 7 July 2014. Accepted 2 February 2015. This study has received financial support from the Government of Spain, through its Ministry of Economy and Competitiveness, project ECO 2012-33286. It has also received backing from the European Social Fund and the government of Aragon, through the Research Group «Agrifood Economic History» (19 ${ }^{\text {th }}$ and $20^{\text {th }}$ centuries). The authors are especially grateful to Juan Huitzilihuitl Flores Zendejas and Raúl Serrano for their help. They also received helpful comments and suggestions from Fernando Collantes, Joseph Francis, Domingo Gallego, Alfonso Herranz, Agustina Rayes, Xavier Tafunell, Jeffrey G. Williamson and participants at the XVI World Economic History Congress, the Conference on Trade, Poverty and Growth in History organized by the Carlos III University and the Fundación Ramón Areces and seminars at the Pompeu Fabra and Zaragoza universities. The authors also thank three anonymous referees for their helpful comments. The usual disclaimers apply.

a Department of Applied Economics and Economic History, Faculty of Economics and Business Studies, University of Zaragoza, Gran Via 4, 50005 Zaragoza, Spain. vpinilla@unizar.es

b Independent Scholar, 14505 E. Walnut Run, Fort Wayne, IN 46814, Fort Wayne, Indiana, USA. aparicio4@gmail.com 


\section{RESUMEN}

El objetivo del artículo es ofrecer evidencia empírica sobre el comportamiento de las exportaciones y precios relativos de productos agrarios y alimentos de América del Sur, entre 1900 y 1950. Estos, fueron años de intensas turbulencias que afectaron profundamente a los países de la región, lo que generó un hondo pesimismo sobre la potencialidad del modelo de desarrollo dirigido por las exportaciones. El trabajo presenta una base cuantitativa nueva para analizar la evolución de las exportaciones de productos agrarios y alimentos de Sudamérica entre 1900 y 1950. También ofrece una serie de términos de intercambio para las exportaciones agrarias de Sudamérica, que utiliza por primera vez para su construcción los pesos relativos en éstas de los distintos productos agrarios.

Palabras clave: Historia Económica Latinoamericana, Comercio internacional agroalimentario, Gran Depresión, Términos de intercambio

\section{INTRODUCTION}

As is well known, the international economy underwent a series of fundamental shocks in the first half of the XX century, profoundly changing the bases upon which it had developed in the previous century. The early years can be seen as the pinnacle of the first globalisation. The First World War was the first important impact, but once ended the desire of the majority of governments was to restore the previously existing system of economic relations. However, the crisis of 1929 and the deep depression encompassing the planet in the 1930s ended this globalisation (Hynes et al. 2012). The Second World War, its global reach and its tremendous impact upon European countries, which had been the principal promoters of the first globalisation, only fractured international economic relations even more deeply. The end of military operations and the reconstruction and reorganisation of international economic relations gave way to a second wave of globalisation which has lasted until today. However, until the 1980s it was above all the developed countries which truly participated in globalisation. For political reasons the centrally planned economies excluded themselves from the process of integration. Additionally, a considerable number of developing countries, although they did not radically break their connections with the international economy, did reduce and modulate them, with the objective of prioritising inward-looking development strategies (Findlay and O'Rourke 2007).

The countries of South America had specialised in the international division of labor generated by the first globalisation in the export of primary products, both agricultural and mineral. The weight of such products in their 
exports was considerable, and at the same time represented a significant percentage of exports in world trade. Precisely, the rapid economic growth of the region until the First World War and the high level of GDP per capita attained by some South American republics have been principally explained by their success as agricultural exporters (Bulmer-Thomas 1994).

However, the turbulence and problems for exporters of primary products in the years 1914-1945 had a severe impact on the strategies of economic growth followed after the second post-war period. The difficulties which, above all in the 1930s, were faced by agricultural exporters in their traditional European markets and the instability in the terms of trade, and similarly their downward trend from that decade onwards, caused deep pessimism regarding the continuity of the model of growth based on exports of primary products (Cárdenas et al. 2000, pp. 13-14; Paiva Abreu 2006, p. 121).

It is important to emphasise the profound impact on the founder and most renowned Latin American economist of the structuralist school, Raul Prebisch, of the difficulties in the late 1920s and the 1930s. In their analyses of the Argentine economy of the 1920s, Prebisch and his collaborators signaled the existence of an "Argentine business cycle» which exhibited clear economic fluctuations and was explained principally by the instability of exports and the arrival of foreign capital (Love 1996, pp. 408-411; O'Connell $1988,2001)$. For them, export instability was largely determined by price and demand oscillations for exported products. The result, in the opinion of Prebisch, was the extreme vulnerability of the Argentine economy, faced with the instability emanating from abroad (O'Connell 2001, pp. 55-60). The vicissitudes of the Argentine economy in the 1930s, and especially the sharp decline in the relative prices of its export products, reinforced his vision. The quasi-monopsonistic British position for Argentine exports of meat, and the subsequent Argentine weakness in trade negotiations following the RocaRunciman Treaty of 1933 until later bilateral agreements such as that of 1936 or those of the war years, also made a strong impression on Prebisch (Love 1996, pp. 405-406).

Given the strong leadership enjoyed by Prebisch in the Economic Commission for Latin America (ECLA, or in Spanish, CEPAL), it is unsurprising that his ideas were reflected in the approach of this organisation, founded in 1948, especially when it is borne in mind that before being its director, he had published in Santiago de Chile in 1949 his seminal work «The development of Latin America and its principal problems». Thus, in the original formulation of the ECLA to justify import substituting industrialisation (ISI), the decline in the terms of trade for primary products and the lack of a market with sufficient capacity to absorb them played a crucial role in explaining the limits to growth imposed by the export-led development model. In this way, ISI appeared to be an alternative to absorb the redundant labor in the primary sector and, in addition, to generate technological progress and a sharp boost to economic development through industrialisation 
(Fitzgerald 2000, pp. 60-63). The industrialist vision of the ECLA, according to Love (1996, p. 394) was after 1930 a response both to a fact, the decline of the export-led growth model, and a «solution» to the problem of economic underdevelopment. Until 1949, in general, there existed no powerful theory which defended the ISI model, which was instead a "pragmatic» solution to the difficulties faced by Latin American economies.

Given this context, the objective of the present study is to offer empirical evidence regarding the behaviour of exports and relative prices of agricultural and food products of South America in these years of great economic turbulence. Consequently, we attempt to analyse with precision their evolution in a period which was key in the formation of a new school of economic thought; one leading the majority of Latin American countries to make a radical turn in their strategies for economic growth following the Second World War. That is to say, the question to be answered is whether the «export pessimism» so deeply rooted among Latin American thinkers and policymakers at the end of the 1940s had firm objective foundations. To do this, the study offers a new quantitative base to analyse the evolution of exports of agricultural and food products from South America in the complicated period between 1900 and 1950. The paper also constructs a terms of trade series for South American agricultural exports; we believe this is the first time such a series for the evolution of the terms of trade in the region for this period which takes into account in its construction the relative weight of the exports of the distinct agricultural products has been offered. This series permits the analysis of not only the evolution of exports by volume, but also the evaluation of their purchasing power as a consequence of the simultaneous evolution of prices and quantities.

The study concludes by demonstrating the severity of the external shocks faced by South American exporters. Despite this, there was in general a dynamic reaction which even permitted the volume of exports to increase during the Great Depression. The South American share of worldwide exports of agrifood products increased until reaching its peak towards 1950, although the level of agrifood exports from South America was in this year lower in volume than that of the pre-war period. The evolution of the terms of trade was however very unfavourable for these countries from the mid 1920s until the 1950s. The so-called «export pessimism», present in the works of economists such as Raul Prebisch and supported by many policymakers, was decisive in understanding the volte-face in the development model after 1950.

The article continues with a synthetic presentation of the sources used for the construction of the data series. Subsequently, it provides an explanation of the position of South America in the world market for agricultural products on the eve of the First World War. The following section analyses, first, the impact of the war on the volume of agricultural exports from the region and, second, that of the Great Depression and finally the situation for South American exports in the Second World War and the subsequent years. 
The following section explores the evolution of the terms of trade for South American agricultural exports throughout the period analysed. Finally, some conclusions are presented.

\section{DATA}

For the years 1900-1938 the IIA offers information on the trade undertaken, in quantities, for sixty-two products and for the world as a whole, permitting the construction of an annual index of the volume of global agricultural trade (Aparicio et al. 2009).

This annual series provides information on the evolution of trade worldwide, but does not permit its disaggregation by continents. Such disaggregation is possible using the five-yearly averages published by the IIA for the years 1909-1913, 1924-1928 and 1928-1932. For the years 1932-1936 the present authors have been able to elaborate another average, based on annual data published by the IIA ${ }^{1}$. The statistics from the IIA and the Food and Agriculture Organization (FAO) are based on the official data from each country. Their reliability therefore depends on that of the diverse national statistics. Their principal problems are the valuations used, that is to say the prices utilised. For Latin America, and for the years of our study, CarrerasMarín and Badía-Miró (2008), Tena and Willebald (2013) and Rayes (2015), have emphasised that the principal problems of its foreign trade statistics are both the valuations applied and the geographical distribution by destination of exports. As this study uses data by volume, without taking destination into account, we believe that we are not confronted with these problems and we can be confident that these data reasonably reflect reality. An additional problem of the IIA statistics arises when reexports exist, as some countries include them without distinguishing origin. In this case do not we have this type of problem either, since in these countries there were no significant reexports of the products studied.

The averages of the quantities exchanged of all products have been multiplied by their prices in the year 1925, obtained principally from the same source, to be able to aggregate trade in all products.

In some cases, especially in the first two 5-year periods, it has been necessary to perform certain estimations ${ }^{2}$. These 5-yearly averages, constructed for each of the sixty-two products and subsequently grouped according to the SITC 2 classification, permit analysis of the evolution of South American exports between the early years of the XX century and the outbreak of the Second World War.

To analyse the impact of the Second World War and the early post-war years we have calculated an annual series of South American exports

\footnotetext{
1 See online Appendix.
}

2 See online Appendix. 
between 1925 and 1951, comprised of eight products (wheat and wheat flour, maize, coffee, linseed, cotton, cocoa, beef and wool), which constituted $\sim 85$ per cent of exports ${ }^{3}$. Our data source has been the above-mentioned IIA yearbooks, a later volume published jointly by the IIA and the FAO in the transition from one organisation to the other, which covers the years 1939-1945 (IIA-FAO 1947), and the subsequent FAO yearbooks for the years 1946-1951.

For the years 1951-1960, data for agricultural and food trade were sourced from the trade figures compiled by the FAO of the United Nations (FAO 1947-1960). The principal shortcoming of these data is that only a relatively small number of countries were included in the yearbooks until approximately 1960; coverage extended to most of Europe but was far from complete for the rest of the world. Consequently, it has been necessary to make a number of estimates ${ }^{4}$.

Based on these sources, we obtained a homogeneous, representative annual series for total agricultural trade at current prices. To obtain a data series for international agricultural trade by volume, we constructed price indices for the various product groups and then employed them to deflate the relevant current price series (see Serrano and Pinilla 2010, Appendix).

Additionally, we constructed a series to measure the evolution of the terms of trade for exports of agricultural products and food from South America with regard to imports of manufactures from industrialised countries. To do this we used the products and price series of Gilli and Yang (1988), which have recently been corrected and broadened by Pfaffenzeller (2007). To this end, we firstly obtained an annual price series, weighted by the share of each product in South American exports of the distinct products considered in the Grilli-Yang index in 1924-1928. Deflating this series by the prices of the imports of manufactures from the industrialised countries, we obtained a regional series for the terms of trade of South American agricultural exports ${ }^{5}$. It must be underlined that the products included in this series represent an extremely high percentage (88-92 per cent) of South American agricultural exports in the period 1900-1938. With the aid of the terms of trade series constructed, it is also possible to analyse the evolution of the purchasing power of agrifood exports.

\section{SOUTH AMERICA AT THE APEX OF THE EXPORT MODEL}

Since the mid-XIX century the South American republics had tended to position themselves as exporters of primary products in the international division of labor which took place in the first globalisation. European demand for these products, in a context of the reduction of international

\footnotetext{
3 See online Appendix.

4 See online Appendix.

5 See online Appendix.
} 
transport prices and of trade liberalisation, generated attractive opportunities to increase exports from those countries specialising in such products.

To permit the increase of exports from the region, it was first necessary to reallocate land towards crops for which there was demand in the international market or to cultivate new lands. In some countries, such as Argentina, Uruguay or southwest Brazil the vast existing plains (the pampa), used until then by the indigenous populations, had first to be conquered. Subsequently, there commenced a formidable process of agricultural frontier expansion similar to that which occurred in other countries such as the United States, Canada or Australia (Cortés Conde 1992; Barksy and Gelman 2001).

Between 1850 and 1914 exports from the Latin American countries increased at an impressive annual rate of 3.5 per cent (Bértola and Williamson 2006, p. 28). The most successful cases for the economic development of this type of specialisation were the nations recently colonised by European countries (settler countries). They include Argentina and Uruguay, which undertook in this period an intense process of territorial colonisation and expansion of their exports $^{6}$. An abundant provision of land suitable for agricultural production, characteristic of temperate zones, a significant supply of workers proceeding from Europe and a considerable entry of foreign capital facilitated and stimulated this process of export-led growth.

The remaining countries of South America also oriented their economies in this same direction, although the results, except in the case of Chile, were much more modest. Thus, exports per capita from Argentina and Uruguay reached, between 1870 and 1912, levels situated between those of Canada and Australia, and those of Chile were close, while those of Bolivia, Brazil, Colombia, Ecuador, Paraguay, Peru and Venezuela were considerably lower (Bulmer-Thomas 1994, p. 89). The degree of openness of these countries was high. The data of Maddison (2001, p. 194 and 362) show that the ratio of exports to GDP in 1870 in South America was higher than that of any other world region, although by 1913 it had been overtaken by Western Europe and Africa. Nevertheless, its weight in world trade was small, constituting 5.3 per cent in 1870 and 5.1 per cent in 1913.

South American exports displayed a marked specialisation in primary products and within these in food and agricultural products. Thus, of the ten republics which were independent in 1913, in seven the principal export product was agricultural. In Bolivia and Chile the two principal export products were minerals, which accounted in 1913 for over 75 per cent of total goods exported. In Colombia and Peru, mineral exports also had a considerable weight, since the most significant of these were gold in

6 The average annual compound rate of merchandise export growth of Argentina between 1870 and 1913 was 5.2 per cent. The median of the seven largest economies of Latin America was 3.4 per cent (Salvucci 2006, p. 253). In 1913 Argentina and Uruguay had by far the highest exports per capita of Latin America (Bulmer-Thomas 1994, p. 183). 
Colombia (20 per cent of total exports) and copper in Peru (22 per cent of the total). Thus, the principal agrifood exporters, by their weight in total South American exports, were Argentina, Brazil and Uruguay ${ }^{\text {. The con- }}$ centration of exports on a limited number of products was also very high. The two principal export products of all the South American republics, which were always agricultural or mineral products constituted between 40 per cent and 80 per cent of the total exports of each country (BulmerThomas 1994, p. 59).

Table 1 shows that on the eve of the First World War South America had a very significant weight in international trade in food and agricultural products, since it constituted 11.9 per cent of the world total. This prominent position in the international market had been achieved thanks to the strong growth of agricultural production in the preceding decades. The increase in the agricultural output of South America between 1870 and 1913 far outweighed that of the world as a whole and that of any of its regions ${ }^{8}$. Its export orientation is even clearer if it is borne in mind that its population in 1913 was only 3.1 per cent of that of the world (Yañez et al. 2014).

South American agricultural exports were heavily concentrated on food, as compared with raw materials (Table 2). Thus, while in the rest of the world there was a greater balance between exports of food and agricultural raw materials, in South America the former represented 70 per cent of its exports in 1909-1913.

The composition of South American exports displays two very different types of specialisation, well represented by two countries of enormous weight in this region, namely Argentina and Brazil. Argentina, and other territories surrounding the Río de la Plata, such as Uruguay, or the southwest of Brazil itself (the Brazilian pampa), had specialised in the production and export of products characteristic of agriculture in temperate zones. Thus, cereals, meat and wool were of great importance in the agricultural production of this South American region. In turn, in the tropical regions, the stellar product was coffee, in which Brazil traditionally specialised and in whose production other countries, especially Colombia, had come to participate.

Consequently, the principal agricultural products of the temperate zones, such as cereals, meat and wool constituted a very high percentage of

7 Before the Second World War, Argentina accounted for $~ 75$ per cent of South American agrifood exports. Following the war its participation contracted to 50 per cent of such exports. Brazil and Uruguay were the following countries in order of importance. The weight of Brazil increased from 10 per cent to 25 per cent. Uruguay constituted throughout the period between 10 per cent and 15 per cent.

${ }^{8}$ In this period, the rate of growth of agricultural value added of South America was 4.9 per cent annually, while world growth was 1.5 per cent. All other regions had rates between 0.9 per cent and 2.1 per cent (Federico 2004, p. 132). 
TABLE 1

WORLD EXPORTS OF AGRICULTURAL AND FOOD PRODUCTS, 1900-1938 (AT 1925 PRICES)

\begin{tabular}{|l|c|c|c|c|}
\hline & 1909-1913 & 1924-1928 & 1928-1932 & 1934-1938 \\
\hline Europe & \multicolumn{4}{|c|}{ Percentages } \\
\hline North and Central America & 20.7 & 21.6 & 21.6 & 17.5 \\
\hline South America & 11.9 & 13.5 & 13.2 & 14.2 \\
\hline Asia & 20.2 & 27.1 & 29.6 & 33.3 \\
\hline Africa & 5.2 & 6.0 & 6.8 & 8.8 \\
\hline Oceania & 6.6 & 7.0 & 8.0 & 9.7 \\
\hline World & 100.0 & 100.0 & 100.0 & 100.0 \\
\hline & & Index numbers, $1909-1913=100$ \\
\hline Europe & 100 & 80 & 83 & 63 \\
\hline North and Central America & 100 & 157 & 136 & 103 \\
\hline South America & 100 & 148 & 150 & 152 \\
\hline Asia & 100 & 175 & 199 & 211 \\
\hline Africa & 100 & 152 & 178 & 216 \\
\hline Oceania & 100 & 137 & 164 & 187 \\
\hline World & 100 & 131 & 136 & 128 \\
\hline
\end{tabular}

Sources: Online Appendix, Table A.1.

South American exports, which in 1909-1913 accounted for $~ 55$ per cent of their total agricultural and food exports. Coffee, cacao and sugar accounted for somewhat over 30 per cent of these exports. In reality, exports were highly concentrated on a very limited number of products. Only five products, which in order of importance were coffee, wool, wheat, maize and beef, constituted in those years 76 per cent of the agricultural exports of South America (Table 3). For these products exports from this region achieved very high percentages of world totals, as in the case of coffee, beef, wool and maize. For other products which constituted a lower percentage of exports, the region was very strongly positioned in the world market; this was the case of lamb, bananas, cacao, linseed or rubber. 
TABLE 2

BREAKDOWN OF EXPORTS OF AGRICULTURAL AND FOOD PRODUCTS, 1900-1938 (percentages) (at 1925 prices)

\begin{tabular}{|c|c|c|c|c|c|}
\hline $\begin{array}{l}\text { SICT } 2 \\
\text { codes }\end{array}$ & World & $\begin{array}{l}1909- \\
1913\end{array}$ & $\begin{array}{c}1924- \\
1928\end{array}$ & $\begin{array}{l}1928- \\
1932\end{array}$ & $\begin{array}{l}1934- \\
1938\end{array}$ \\
\hline 0 & Food and live animals chiefly for food & 54.3 & 55.7 & 55.1 & 52.3 \\
\hline 00 & Live animals & 1.0 & 2.9 & 2.7 & 2.4 \\
\hline 01 & Meat and preparations & 4.3 & 5.7 & 5.2 & 4.7 \\
\hline 02 & Dairy products and eggs & 5.9 & 6.3 & 6.5 & 6.5 \\
\hline 04 & Cereals and cereal preparations & 21.7 & 17.2 & 16.9 & 14.8 \\
\hline 05 & Vegetables and fruit & 4.6 & 5.0 & 5.1 & 5.4 \\
\hline 06 & Sugar, sugar preparations and honey & 8.9 & 11.4 & 11.2 & 10.2 \\
\hline 07 & $\begin{array}{l}\text { Coffee, tea, cocoa, spices and } \\
\text { manufactures thereof }\end{array}$ & 7.8 & 7.3 & 7.4 & 8.3 \\
\hline 1 & Beverages and tobacco & 2.6 & 2.8 & 2.9 & 2.7 \\
\hline 11 & Beverages & 1.0 & 0.8 & 0.9 & 0.9 \\
\hline 12 & Tobacco and tobacco manufactures & 1.7 & 2.0 & 2.0 & 1.8 \\
\hline 2 & Crude materials, inedible, except fuels & 41.5 & 39.6 & 40.0 & 42.7 \\
\hline 22 & Oil seeds and oleaginous fruit & 4.6 & 4.7 & 5.1 & 5.5 \\
\hline 23 & Crude rubber & 2.5 & 7.7 & 8.8 & 11.1 \\
\hline 26 & $\begin{array}{l}\text { Textile fibers (not wool tops) and } \\
\text { their wastes (not in yarn) }\end{array}$ & 34.4 & 27.2 & 26.1 & 26.1 \\
\hline 4 & $\begin{array}{l}\text { Animal and vegetable oils, fats and } \\
\text { waxes }\end{array}$ & 1.6 & 1.9 & 2.1 & 2.3 \\
\hline \multirow[t]{3}{*}{42} & Fixed vegetable oils and fats & 1.6 & 1.9 & 2.1 & 2.3 \\
\hline & Total & 100.0 & 100.0 & 100.0 & 100.0 \\
\hline & South America & & & & \\
\hline 0 & Food and live animals chiefly for food & 69.5 & 75.8 & 75.2 & 71.2 \\
\hline 00 & Live animals & 0.6 & 2.2 & 1.4 & 1.1 \\
\hline 01 & Meat and meat preparations & 10.7 & 16.0 & 12.7 & 10.9 \\
\hline 02 & Dairy products and eggs & 0.3 & 1.2 & 1.0 & 0.6 \\
\hline
\end{tabular}


TABLE 2 (Cont. )

\begin{tabular}{|c|c|c|c|c|c|}
\hline $\begin{array}{l}\text { SICT } 2 \\
\text { codes }\end{array}$ & & $\begin{array}{l}1909- \\
1913\end{array}$ & $\begin{array}{l}1924- \\
1928\end{array}$ & $\begin{array}{l}1928- \\
1932\end{array}$ & $\begin{array}{l}1934- \\
1938\end{array}$ \\
\hline 04 & Cereals and cereal preparations & 24.1 & 26.8 & 30.0 & 26.4 \\
\hline 05 & Vegetables and fruit & 3.1 & 3.4 & 2.2 & 3.0 \\
\hline 06 & Sugar, sugar preparations and honey & 3.0 & 3.3 & 3.8 & 4.2 \\
\hline 07 & $\begin{array}{l}\text { Coffee, tea, cocoa, spices and } \\
\text { manufactures thereof }\end{array}$ & 27.7 & 22.9 & 24.0 & 25.0 \\
\hline 1 & Beverages and tobacco & 0.9 & 0.9 & 1.0 & 0.9 \\
\hline 11 & Beverages & 0.0 & 0.0 & 0.0 & 0.0 \\
\hline 12 & Tobacco and tobacco manufactures & 0.9 & 0.9 & 0.9 & 0.9 \\
\hline 2 & Crude materials, inedible, except fuels & 29.6 & 23.2 & 23.8 & 27.7 \\
\hline 22 & Oil seeds and oleaginous fruit & 5.0 & 7.4 & 8.1 & 7.8 \\
\hline 23 & Crude rubber & 4.4 & 1.8 & 1.1 & 1.0 \\
\hline 26 & $\begin{array}{l}\text { Textile fibers (not wool tops) and } \\
\text { their wastes (not in yarn) }\end{array}$ & 20.2 & 14.0 & 14.5 & 18.9 \\
\hline 4 & $\begin{array}{l}\text { Animal and vegetable oils, fats and } \\
\text { waxes }\end{array}$ & 0.0 & 0.1 & 0.0 & 0.2 \\
\hline \multirow[t]{2}{*}{42} & Fixed vegetable oils and fats & 0.0 & 0.1 & 0.0 & 0.2 \\
\hline & Total & 100.0 & 100.0 & 100.0 & 100.0 \\
\hline
\end{tabular}

Sources: Online Appendix, Table A.2.

\section{THE IMPACT OF EXTERNAL SHOCKS ON THE VOLUME OF SOUTH AMERICAN AGRICULTURAL AND FOOD EXPORTS}

\subsection{The First World War and the 1920s}

The outbreak of the First World War in 1914 marked the beginning of the end of the system of international economic relations which had been articulated throughout the XIX century. The war seriously affected international exchanges and, logically, most particularly the countries most dependent on trade, such as the South American economies, whose growth was driven by exports. The submarine war and the shortage of ships increased transport costs. Furthermore, there were time-specific changes in 
TABLE 3

TOP FIVE AGRICULTURAL EXPORTS FROM SOUTH AMERICA (exports at 1925 prices) (in thousands of USA dollars)

\begin{tabular}{|l|l|c|c|c|c|}
\hline $\begin{array}{l}\text { SITC 2 } \\
\text { codes }\end{array}$ & & $\begin{array}{c}\mathbf{1 9 0 9 -} \\
\mathbf{1 9 1 3}\end{array}$ & $\begin{array}{c}\mathbf{1 9 2 4} \\
\mathbf{1 9 2 8}\end{array}$ & $\begin{array}{c}\mathbf{1 9 2 8 -} \\
\mathbf{1 9 3 2}\end{array}$ & $\begin{array}{c}\mathbf{1 9 3 4 -} \\
\mathbf{1 9 3 8}\end{array}$ \\
\hline 0111 & $\begin{array}{l}\text { Bovine meat, fresh, } \\
\text { chilled or frozen }\end{array}$ & 112,630 & 266,842 & 207,269 & 184,214 \\
\hline $041 / 046$ & Wheat & 162,164 & 251,566 & 269,813 & 206,950 \\
\hline 044 & Maize & 120,619 & 222,452 & 270,543 & 269,161 \\
\hline 071 & Coffee & 334,958 & 407,518 & 436,996 & 457,401 \\
\hline 268 & $\begin{array}{l}\text { Wool and other animal } \\
\text { hair }\end{array}$ & 239,103 & 225,400 & 229,608 & 211,955 \\
\hline $\begin{array}{c}\% \text { of total South American } \\
\text { agricultural exports }\end{array}$ & 75.8 & 72.6 & 73.5 & 68.2 \\
\hline
\end{tabular}

Source: Authors' compilation, based on IIA, 1910-1939.

the demand for products, depending on their interest for the countries at war (Albert 1988, pp. 55-121).

The volume of international trade in food and agricultural products declined from the maximum reached in 1913 until the minimum of 1918, which was only 56 per cent of the former level (Aparicio et al. 2009, pp. 69-70). The pre-war level was not to be reached until 1925. As is logical, the impact of the war was highly varied in the diverse regions of the world; it was greater in the zones directly affected by the conflict and less important in the countries furthest removed from the theatre of operations.

South America showed the vulnerability of an economy open to the destabilisation of international economic relations, its exports initially falling. Nevertheless, the importance of some of its products for the allied countries meant that they tended to recover their previous levels immediately. Thus, countries such as Chile or Peru ended the war with a volume of exports higher than that of 1913, while those of Argentina or Brazil oscillated notably and behaved more poorly (Albert 1988, pp. 56-61).

The end of the war marked an apparent return to normality, although the international economy had changed considerably. Instability in Europe, monetary problems and economic difficulties in some countries cast doubts over the possibilities of success of the agroexporting model. Additionally, the shift of economic hegemony from the United Kingdom to the United States had important consequences for the South American countries, whose trade was strongly linked to Europe and especially to the United Kingdom. The new power was less dependent on certain imports than the United Kingdom, 
and was in fact an important competitor in the international market for some products proceeding from the temperate zones of South America.

Despite all the above, the agroexporting model was not yet seriously questioned in South America, and in fact the First World War reinforced the central role of primary exports. In terms of the volume of exports, the conflict was the culmination of the agroexporting model, as shown in Table 1 and indicated by various authors (Díaz Alejandro 1988).

Nevertheless, the new scenario was to be complicated, not only for the reasons above, but also due to a much slower increase in the demand for many primary products. A high level of income per capita in many importing European countries already implied a less than proportional growth in demand (Malenbaum 1953). Population growth weakened, due to the advanced state of the demographic transition in the most developed countries. In turn, synthetic products began to appear which weakened demand still further and increased concurrence in the market. Additionally, supply increased quickly, driven partly by certain technological innovations, and by the opportunities which had existed until then, making many countries decide to attempt to increase their exports to take advantage of them.

The volume of world trade in food and agricultural products following the war made a rapid recovery. This process commenced in 1919 and by 1925 trade was once again at 1913 levels. After 1925 growth was very rapid, such that in 1929 it reached a maximum which would not be recovered until years after the Second World War (Aparicio et al. 2009, pp. 69-70).

In this complex context, the response of the South American countries was to intensify their agroexporting specialisation. The success of this strategy, in terms of increasing their volume of trade, was considerable. Comparing the increase in the volume of agricultural trade between 19091913 and 1924-1928 (Table 1), South America is notable as one of the world regions in which this grew most, although less than in Asia, Africa and North and Central America. As a result, its participation in world agricultural trade increased until it constituted 13.5 per cent.

The sharp rise in the volume of agricultural exports throughout the 1920s was based above all on a formidable expansion of the exports in which South America was most highly specialised, namely food. It is important to emphasise that the improvement of these exports took place in both the foods characteristic of the agriculture of temperate zones and in those of tropical zones.

In the first case, the most notable aspect was the increase in the exports of meat, which far outweighed the pre-war level. Particularly important within meat was beef, especially frozen beef from the Río de la Plata, which was behind this expansion. As a consequence, South America almost achieved a monopoly in world markets, constituting 75 per cent of its trade (Argentina by itself represented 58 per cent and Uruguay 11 per cent). The increase in the exports of beef took advantage of a drastic change in the international 
meat trade as a consequence of the adoption of meat-freezing technologies for transport. The availability of such technologies led the United Kingdom to prohibit in 1892 (Diseases of Animals Act) the importation of live cattle from the European continent, benefiting South American exports. A new technology, the chilling of meat instead of freezing, stimulated South American exports still further, due to the preference of British consumers for this type of meat (Empire Marketing Board 1932, p. 14). Furthermore, the increase of per capita income in the industrialised countries led to a sharp rise in the demand for meat. It has also been indicated that the effects of the war upon cattle herds in countries such as Germany and France stimulated the meat trade, as did a trade policy of low tariffs until 1925 (Bacon and Schloemer 1940, p. 183). Between 1909-1913 and 1924-1928 world trade in meat doubled in volume. The increase in South American exports was even greater, meaning that it was not only capable of maintaining its advantageous position in the market, but even of strengthening it. Thus, from constituting 29 per cent of world trade in meat in the first period, it came to represent 38 per cent in the second.

Results in cereal exports were also important. Exports of wheat and maize increased spectacularly, reaching in the latter case an extremely high proportion of world trade (63 per cent in 1924-1928).

In the case of wheat, Argentina took advantage of the withdrawal of the new Soviet state as an exporter after 1917, which seriously affected the world market, since the former Imperial Russia had in 1909-1913 a 20 per cent share of world exports, while in the 1930 s this figure was $<5$ per cent. Following the First World War, the countries of the Danube basin, which were also important exporters, accounting for 15 per cent of world exports in 1909-1913, reduced to approximately half their quota of exports, as a consequence of the agricultural reforms undertaken in many of them, meaning the fragmentation of large farms, changes in the uses of land and an increase of domestic consumption due to rising per capita income (Taylor 1928). Argentina took advantage of the withdrawal from the international market of these large exporters and succeeded in substantially increasing its wheat exports. While in 1909-1913 it accounted for 12 per cent of world exports, in 1928-1932 this figure reached 19 per cent. Its experience was not exceptional; other countries such as Canada, Australia or the United States also benefited from the new post-war situation and considerably increased their exports (Aparicio and Pinilla 2015).

The expansion of maize exports resulted principally from the need for cattle feed. The South American share of trade rose above all as a consequence of the increase in the land cultivated for maize, from the early 1920s onwards. The richness of natural pasturelands in Argentina meant that its domestic consumption was very low and that the favoured orientation of production was towards exports. The Argentine share of trade increased prodigiously, rising from 41 per cent of world exports in 1909-1913 to 
68 per cent in 1928-1932. Paradoxically, South America never constituted more than 15 per cent of maize world production.

Elsewhere, tropical agriculture, which was already highly specialised in coffee, achieved a substantial increase in exports, for which the South American share of the world market was 72 per cent in 1924-28. This figure was a very good reflection of the weight of South America in the world production of coffee, which throughout the first third of the XX century oscillated between 73 per cent and 79 per cent. Brazil was the largest producer, at around 60 per cent of the world total, while Colombia in 1909-1913 accounted for $<4$ per cent, reaching over 10 per cent at the end of the 1930 s (IIA 1910-1939).

The increase in the exports of coffee benefited from the substantial increase in consumption in the first third of the XX century; this was $~ 36$ per cent in absolute terms. The largest part of this increase was a consequence of the increase in consumption in the United States, which almost doubled (by 77 per cent), while the rise in the principal importing region, Europe, was very small (only 5 per cent) (Commodity Research Bureau 1939, p. 315). The significant improvement in North American incomes accounted for a substantial increase in the consumption of coffee, especially to the detriment of tea. Consumption was also fairly elastic with regard to price. The price falls of the 1930s facilitated an additional increase in consumption (Wickizer 1943, pp. 51-53). Not only did consumption increase, but tastes in the preferred type of coffee also changed. Especially in the country responsible for the greatest increase in consumption, the United States, milder coffees from Colombia were favoured, causing the Brazilian quota of world exports to fall substantially, dropping from 60 per cent before the First World War to $\sim 50$ per cent in the 1930s. This decline was also influenced by Brazilian public policies of restricting supply. By contrast, Colombia, whose share of world coffee exports was 4 per cent in 1909-1913, accounted for almost 14 per cent in 1934-1938 (IIA, 1910-1939).

Although these were the most dynamic products, exports of the remaining agricultural products behaved quite well in general, helping to explain the substantial expansion of South American exports.

Bulmer-Thomas (1994, p. 199) indicated that Latin American countries followed two alternative strategies in these years to expand their exports. The more successful of these consisted of attempting to increase their share of products for which demand was increasing slowly. Some of the most important products in South American exports, already examined here, such as meat, cereals or coffee, can be included in this category.

The alternative was to depend on the commodity lottery and increase exports by exploiting a strong increase in demand. However, for some of the products which were favoured by this strategy, the results for South America were weak (such as cacao, bananas and sugar) or very poor (especially rubber). In the cases with weak results, African plantations successfully 
competed with those of countries such as Brazil, Ecuador or Venezuela, while those of the Caribbean also provided strong competition in sugar or bananas. Results were very poor in the case of rubber, since Asian plantations benefited from an increase in world trade of $\sim 400$ per cent, which raised the figure of participation in its trade from 37.6 per cent in 1909-1913 to 79.4 per cent in 1924-1928. In contrast, rubber exports from the Amazon region commenced a decline which would extend until the years of the Second World War.

\subsection{The Crisis of 1929 and the Depression of the $1930 \mathrm{~s}$}

The Great Depression which began in 1929 was a tremendous external shock for South America, the countries of the region having no capacity to control it. It seriously affected world trade, both volume and prices falling. This decline has been signaled as the principal line of transmission of the crisis of 1929 to Latin America (Díaz Alejandro 1988). However, one of the principal sources of recovery in South America, following the worst years of the Depression, was the promotion of exports, which recovered from 1931 on. Many governments took active measures to try to ensure the survival of the export sector; some of these were devaluation, the creation of new financial institutions to avoid problems of credit for exporting companies, a moratorium on external debt, the destruction of harvests to maintain prices (in the case of coffee in Brazil), or the establishment of multiple exchange rates (Paiva Abreu 2006, pp. 106-118).

This said, the new scenario was marked not only by declining incomes and the difficulty these caused for world trade, but above all by the deliberate attack on the mechanisms which had facilitated the integration of the international economy since the first third of the XIX century. The end of the first globalisation was definitive from 1929 onwards (Hynes et al. 2012). The agroexporting countries were in this way affected both by the crisis and by the measures taken to limit exchanges and protect national economies. Their impact could however be highly diverse, depending not only on the type of products in which each country specialised but also on the policies which their trade partners practiced (Paiva Abreu 2006, pp. 104-111). For some South American countries such as Argentina, the establishment by Great Britain of the system of imperial preferences in 1932 caused great damage, partially mitigated by the Roca-Runciman agreement of 1933 (Paiva Abreu 1988, pp. 183-185).

Given this context, the evolution of the volume of agricultural exports from South America was not in fact poor. Against the fall in the volume of world trade in agricultural products, South America achieved a slight increase, permitting its share to reach 14.2 per cent (Table 1). In general, the most developed regions of the world, such as Europe and North and Central 
America suffered a collapse of their agricultural exports. At the same time, a slight increase in such exports in Asia or South America or a stronger increase in Africa and Oceania improved the percentage shares of these regions.

The success of the most dynamic regions was based, in the case of Africa, on an improvement in almost all its agricultural exports. This was partly due to advances in the progressive orientation of tropical agriculture towards exports following specialisations induced by the penetration of European colonisation and the start of the exploitation of plantations oriented in this direction. Additionally, in North Africa, the French colonies reinforced their exports towards the metropolis, achieving good results, which were, for example, exceptional in the case of wine, Algeria becoming the principal worldwide exporter by volume (Pinilla and Ayuda 2002).

In Oceania, and principally Australia, the improvement was also generalised in both more traditional exports such as wool and in those which had clearly expanded since the beginning of the XX century, such as dairy products, sugar or meat. The privileged connection of Australia and New Zealand with Great Britain, stimulated by and benefiting from the system of imperial preferences instigated following the Ottawa Conference of 1932, helps to understand these positive results.

Results in Asia, similar in their growth of exports during the 1930s, are explained by the formidable progress in almost a single product, namely rubber. The expansion of the volume of exports of this product was greater than that of the volume of total exports, thereby compensating for the decline of some of them.

The evolution of the volume of South American agricultural exports varied greatly during the Depression. In general, the principal agricultural exports from the temperate zones of South America fell significantly or moderately. Especially important was the reduction of exports of beef or wheat, while the decrease in those of maize, linseed or wool was much more moderate.

For some products, such as wheat, the new framework of trade relations seriously affected export possibilities. The highly protectionist policies of large European importers such as France, Italy or Germany impacted strongly. British policy also damaged exports from countries such as Argentina, which between 1928-1932 and 1934-1938 reduced its exports of wheat by a million metric tonnes. This is not surprising, as in the same period European imports of wheat fell by 5 million tonnes. Maize, however, benefited from less restrictive trade policies, since some countries found insufficient national alternatives to replace imports of this product, essential to feed its cattle herds (Aparicio and Pinilla 2015) ${ }^{9}$.

Exports of meat contracted sharply, decreasing by almost a third. In this case the decrease was notably greater than that of world trade in meat.

${ }^{9}$ Great Britain maintained imports of maize free of tariffs, in contrast to its policy with regard to other cereals (Imperial Economic Committee 1934b, p. 78). 
This meant that a part of the reduction in the volume of exports was explained by falling incomes, which substantially affected a foodstuff with high income elasticity ${ }^{10}$, but the remainder was due to the protectionist policies implemented; these caused a fall in meat imports, while the national production of European countries increased significantly ${ }^{11}$. Particularly important was the system of imperial preference implemented by Great Britain; this significantly encouraged imports of meat from Australia and New Zealand.

The behaviour of the volume of the exports of tropical products was considerably better. Exports of coffee, the principal such item, increased still further throughout the 1930s. Furthermore, products which had previously been of little importance among South American exports occasionally increased sharply. This was the case, for example, of exports of cotton, which more than tripled during the Depression, or those of oranges, which from being insignificant came to account for 10 per cent of their world trade, thanks to Brazil's success in exporting this product (Pinilla and Ayuda 2009, pp. 200-201, 2010). Additionally, increases in the exports of sugar, cacao or tobacco helped tropical agriculture, which nevertheless fell significantly in the case of the export of bananas and rubber.

\subsection{The Second World War and Reconstruction}

The outbreak and development of the Second World War constituted a heavy blow for the South American agroexporting economies. The war was to affect most those in which their foreign sectors had a greater weight in their economies and whose exports were more oriented towards the European market. The occupation by Germany of the majority of the continent and British difficulties in maintaining its exports meant a new blow for the agroexporting model. The German submarine war and the loss of the Asian market, especially the Japanese market, also affected exports. Logically, the exceptional wartime situation not only maintained the mechanisms developed during the Depression for intervention and control over foreign trade, but reinforced them still further. In this context both trade with the United States and interregional trade increased (Carreras-Marín et al. 2013). Although the increase in this type of trade prevented a spectacular collapse of exchanges, their volume fell substantially.

Agricultural products benefited less than minerals from wartime demand, and within agricultural products those proceeding from tropical zones,

10 The consumption of meat in Europe fell during the worst years of the crisis but recovered from 1933 onwards (IIA 1936, pp. 214-321).

11 With regard to the total supply of meat, domestic production rose in Great Britain from 41 per cent in 1942 to 1947 per cent of total consumption in 1934. In Germany national production increased from 90 per cent to 99 per cent and in France the figure rose from 90 per cent to 97 per cent (IIA 1936, pp. 206-275). 
FIGURE 1

ANNUAL VOLUME INDEX OF SOUTH AMERICAN AGRIFOOD EXPORTS, $1925-1951$ (valued at 1938 prices) $(100=1925)$

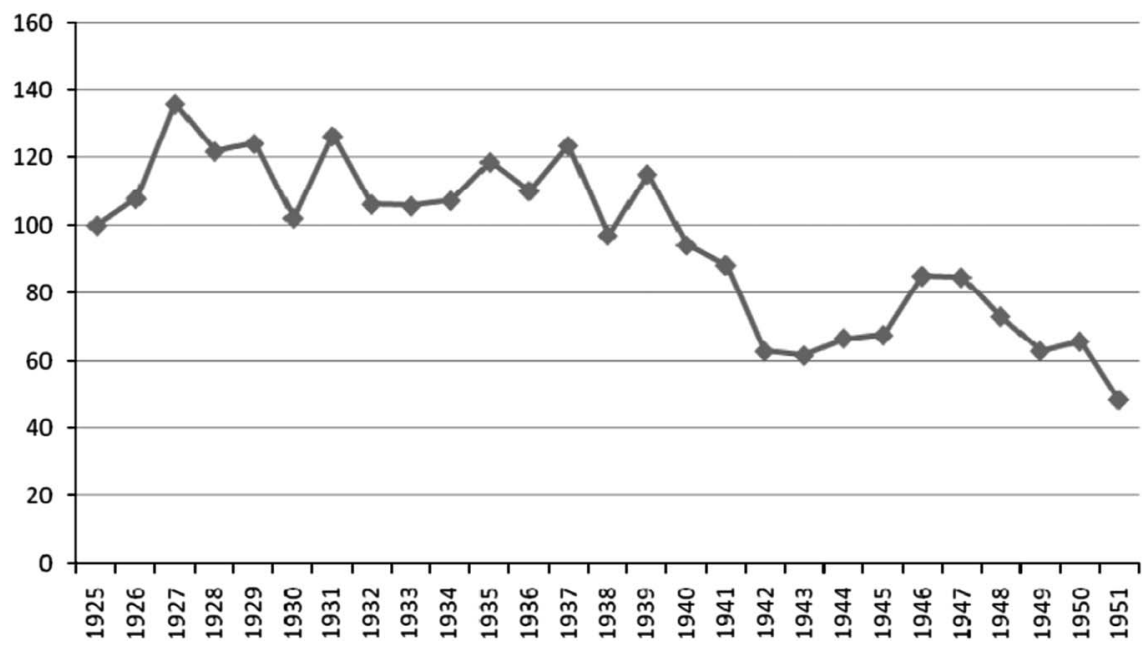

Sources: IIA (1910-1939), IIA-FAO (1947) and FAO (1947-2000).

The index shows the exports of wheat and wheat flour, maize, coffee, beef, wool, cocoa, linseed and cotton. In this period these products accounted for approximately $85 \%$ of total agrifood exports.

which did not compete with North American production, displayed better results than those of the temperate zones, which were more oriented towards the European market. The grain trade was especially affected, since European imports, the principal market for South American exports, were reduced to less than half between 1939 and 1944 (Brassley 2012). Maize exports suffered a spectacular contraction, falling by 93 per cent in 1942-1945 with regard to 1934-1938. Exports of wheat contracted in the same period by 30 per cent. The meat trade withstood the difficult situation better, shrinking by 21 per cent. As a whole, the agrofood exports of South America fell by 42 per cent (Figure 1). Argentina, the principal exporter, was the country most seriously affected by this situation. Uruguay suffered similar problems, while Brazil, as its exports of tropical products to the North American market played a very important role, suffered to a lesser extent.

Paradoxically, peace did not improve the situation in the short term, but instead worsened it for some countries. The demand for strategic products declined and so did the North American preference for Latin American goods, without the European countries being able to substantially increase their imports in the short term. The difficulties in European countries, their 
shortage of currencies and the non-convertibility of the pound sterling complicated the situation yet further. For the exporters of temperate agricultural products, competition with the United States in the international market was an added problem (Cadenazzi 2012). Consequently, export volumes increased very modestly for South American countries. The outbreak of the Korean War improved the situation slightly, but considerably less for agricultural products than for minerals.

However, the difficult European situation during reconstruction, the maintenance of high levels of protectionism and the generalisation of interventionist measures and support for agriculture in Europe, only increased still further pessimism regarding the possibilities of the agroexporting model (Paiva Abreu 2006, p. 121). The exclusion in 1947 of agricultural products from the GATT reinforced this pessimism, on confirming the difficulties foreseen for the dismantling of the complex system of tariff and non-tariff protection which the developed countries had progressively constructed since 1929 and developed yet further during the war and the early post-war years (Cárdenas et al. 2000, pp. 13-14).

Until 1950, the weight of South American exports of agricultural products in world trade was slightly higher than in the pre-war period, namely 17 per cent. However, the volume of exports was in 1950 lower than in the pre-war period (Figure 1; Table 4)

From the mid-1950s onwards the change in the model of development of the principal South American countries was to be of considerable note in the evolution of their exports. Against agricultural trade, which increased worldwide in the 1950s at a remarkably high rate (Serrano and Pinilla 2010), South American exports were those of the only region in the world which significantly diminished in terms of volume. As a consequence, their participation in world agricultural trade fell markedly (Serrano and Pinilla 2011a). The volumes of the two most important South American exports, coffee and cereals, decreased, especially the latter ${ }^{12}$. Although from the $1960 \mathrm{~s}$ the volumes of exports would recover and even increase, their behaviour was hardly dynamic until the 1990s. This lack of dynamism is explained not only by the new inward-looking development model but also by the polarisation of the agrifood trade in regional trade agreements in a context of strong agricultural protectionism in the developed countries and South American specialisation in products of low-income elasticity (Serrano and Pinilla, forthcoming; Table 5).

Composition by products at the beginning of the 1950s showed a strengthening of the weight of food products in South American exports, which as before had a much greater relative weight than in the world as a whole. Moreover, the most notable change in the composition of exports was

12 The Argentinian case is doubtless the most important in demonstrating the decline in exports (Díaz Alejandro 1975; Llach 2006; Hora 2012). 


\section{TABLE 4}

WORLD EXPORTS OF AGRICULTURAL AND FOOD PRODUCTS, 1951-1960 (at 1980 prices)

\begin{tabular}{|l|c|c|}
\hline & $1951-1955$ & $1956-1960$ \\
\hline Europe & 34.2 & 30.5 \\
\hline North and Central America & 21.3 & 26.9 \\
\hline South America & 17.0 & 10.8 \\
\hline Asia & 11.7 & 14.9 \\
\hline Africa & 6.8 & 9.9 \\
\hline Oceania & 9.0 & 7.0 \\
\hline World & 100.0 & 100.0 \\
\hline & Index numbers, 1951-1955 & 100 \\
\hline Europe & 100 & 128 \\
\hline North and Central America & 100 & 181 \\
\hline South America & 100 & 91 \\
\hline Asia & 100 & 182 \\
\hline Africa & 100 & 210 \\
\hline Oceania & 100 & 112 \\
\hline World & 100 & 143 \\
\hline
\end{tabular}

Sources: Online Appendix, Table A.3

a substantial increase in the importance of coffee, while some previously important raw materials such as rubber, and above all wool, suffered a substantial decrease.

5. THE DYNAMICS OF THE TERMS OF TRADE FOR AGRICULTURAL PRODUCTS AND THEIR IMPACT ON THE PURCHASING POWER OF SOUTH AMERICAN AGRICULTURAL AND FOOD EXPORTS

The first decade of the XX century was to mark the end of an extended period which, beginning at the end of the XVIII century, had signified a clear improvement in the terms of trade for the least developed periphery 
TABLE 5

BREAKDOWN OF EXPORTS IN AGRICULTURAL AND FOOD PRODUCTS, 1951-1960 (percentages) (at 1980 prices)

\begin{tabular}{|c|c|c|c|}
\hline $\begin{array}{l}\text { SICT } 2 \\
\text { codes }\end{array}$ & World & $\begin{array}{l}1951- \\
1955\end{array}$ & $\begin{array}{r}1956- \\
1960\end{array}$ \\
\hline 0 & Food and live animals chiefly for food & 68.5 & 65.0 \\
\hline 00 & Live animals & 2.7 & 3.4 \\
\hline 01 & Meat and meat preparations & 9.6 & 8.4 \\
\hline 02 & Dairy products and eggs & 5.5 & 5.0 \\
\hline 04 & Cereals and cereal preparations & 21.5 & 14.5 \\
\hline 05 & Vegetables and fruit & 6.8 & 7.1 \\
\hline 06 & Sugar, sugar preparations and honey & 7.0 & 11.1 \\
\hline 07 & $\begin{array}{l}\text { Coffee, tea, cocoa, spices and manufactures } \\
\text { thereof }\end{array}$ & 13.4 & 12.6 \\
\hline 08 & $\begin{array}{l}\text { Feeding stuff for animals (not including unmilled } \\
\text { cereals) }\end{array}$ & 1.2 & 1.8 \\
\hline 09 & Miscellaneous edible products and preparations & 0.9 & 1.0 \\
\hline 1 & Beverages and tobacco & 9.8 & 9.3 \\
\hline 11 & Beverages & 5.7 & 4.8 \\
\hline 12 & Tobacco and tobacco manufactures & 4.1 & 4.5 \\
\hline 2 & Crude materials, inedible, except fuels & 18.1 & 22.9 \\
\hline 21 & Hides, skins and fur skins, raw & 2.9 & 2.7 \\
\hline 22 & Oil seeds and oleaginous fruit & 1.6 & 3.2 \\
\hline 232 & Crude rubber & 1.4 & 4.0 \\
\hline 26 & $\begin{array}{l}\text { Textile fibers (not wool tops) and their wastes (not } \\
\text { in yarn) }\end{array}$ & 10.4 & 11.0 \\
\hline 29 & Crude animal and vegetable materials, n.e.s. & 1.8 & 2.0 \\
\hline \multirow[t]{3}{*}{4} & Animal and vegetable oils, fats and waxes & 3.5 & 2.8 \\
\hline & Total & 100.0 & 100.0 \\
\hline & South America & $\begin{array}{l}1951- \\
1955\end{array}$ & $\begin{array}{r}1956- \\
1960\end{array}$ \\
\hline 0 & Food and live animals chiefly for food & 85.5 & 80.6 \\
\hline
\end{tabular}


TABLE 5 (Cont. )

\begin{tabular}{|c|c|c|c|}
\hline $\begin{array}{l}\text { SICT } 2 \\
\text { codes }\end{array}$ & & $\begin{array}{l}1951- \\
1955\end{array}$ & $\begin{array}{l}1956- \\
1960\end{array}$ \\
\hline 00 & Live animals & 0.3 & 0.9 \\
\hline 01 & Meat and meat preparations & 10.0 & 12.6 \\
\hline 02 & Dairy products and eggs & 0.1 & 0.6 \\
\hline 04 & Cereals and cereal preparations & 26.1 & 10.4 \\
\hline 05 & Vegetables and fruit & 2.7 & 4.4 \\
\hline 06 & Sugar, sugar preparations and honey & 1.7 & 5.1 \\
\hline 07 & $\begin{array}{l}\text { Coffee, tea, cocoa, spices and manufactures } \\
\text { thereof }\end{array}$ & 44.1 & 44.0 \\
\hline 08 & $\begin{array}{l}\text { Feeding stuff for animals (not including unmilled } \\
\text { cereals) }\end{array}$ & 0.6 & 2.6 \\
\hline 09 & Miscellaneous edible products and preparations & 0.0 & 0.0 \\
\hline 1 & Beverages and tobacco & 0.7 & 1.0 \\
\hline 11 & Beverages & 0.0 & 0.2 \\
\hline 12 & Tobacco and tobacco manufactures & 0.7 & 0.7 \\
\hline 2 & Crude materials, inedible, except fuels & 13.4 & 16.0 \\
\hline 21 & Hides, skins and fur skins, raw & 3.4 & 3.6 \\
\hline 22 & Oil seeds and oleaginous fruit & 1.4 & 0.4 \\
\hline 232 & Crude rubber & 0.0 & 0.1 \\
\hline 26 & $\begin{array}{l}\text { Textile fibers (not wool tops) and their wastes (not } \\
\text { in yarn) }\end{array}$ & 6.6 & 11.4 \\
\hline 29 & Crude animal and vegetable materials, n.e.s. & 2.0 & 0.5 \\
\hline \multirow[t]{2}{*}{4} & Animal and vegetable oils, fats and waxes & 0.3 & 2.4 \\
\hline & Total & 100.0 & 100.0 \\
\hline
\end{tabular}

Sources: Online Appendix, Table A.4

of the world. Williamson (2008) signaled that for the Latin American countries, this boom would have been much more modest but more prolonged, since its crowning point would have been reached in 1895. Between 1895 and 1900 there was a significant fall in these terms of trade in Latin America, 
FIGURE 2

SOUTH AMERICAN TERMS OF TRADE FOR AGRICULTURAL AND FOOD PRODUCTS, $1900-1959(1900=100)$

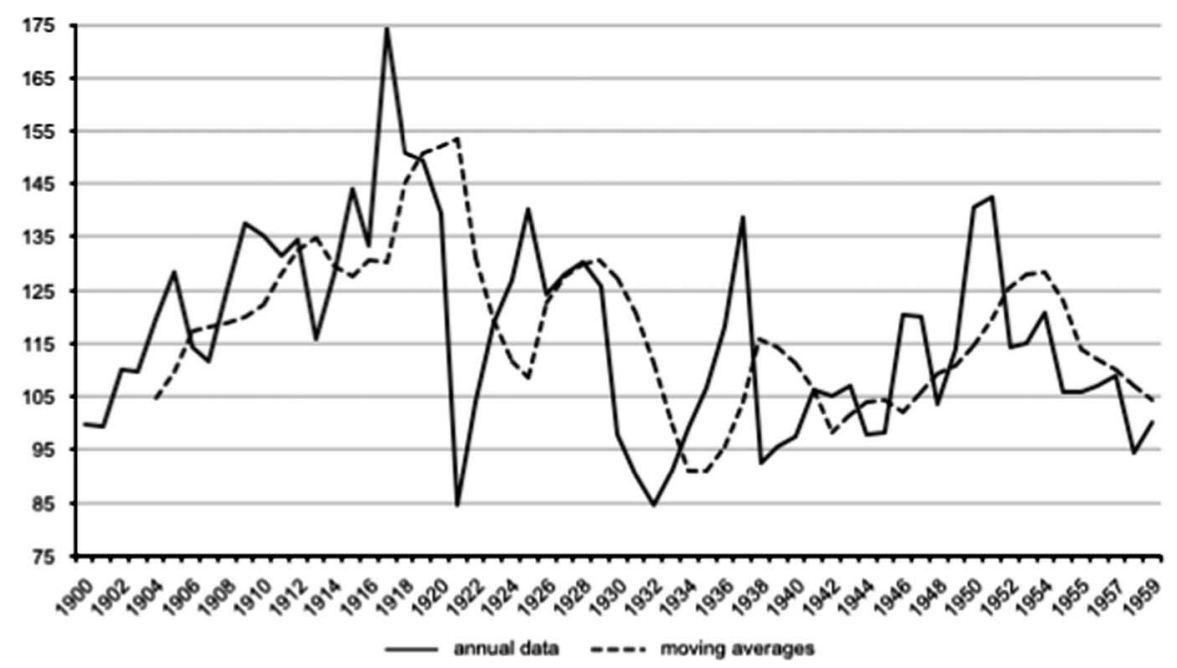

Sources: Authors' elaboration, based on Pfaffenzeller et al. (2007) and IIA (19101939).

without the subsequent rises which took place until the First World War and permitted the maximum of 1895 to be recovered (Bértola and Williamson 2006, p. 33).

Following the final quinquennium of the XIX century, terms of trade for agricultural exports improved until the First World War in the case of the agricultural exports of the countries of South America (Figure 2). The extraordinary circumstantial improvement produced by the First World War must be approached with circumspection. As the index displays highly varied market prices, it does not necessarily reflect exactly the behaviour of the prices paid in South America. An alternative estimation with Argentinian prices shows that the improvement during this situation was notably inferior (Francis 2013).

The end of the war involved a sharp fall in the terms of trade for South American agrifood products, although the subsequent recovery maintained such terms at levels markedly above those of the beginning of the XX century but clearly lower than the maximums reached previously. From 1925 onwards, the terms of trade tended to decline, although moderately. This worsening demonstrates problems of oversupply in the markets for certain agricultural products, as a consequence of both the slow increase in demand and the rapid increase in supply. Products whose growth in demand was 
lower, due to their low-income elasticity or the existence of synthetic substitutes, were especially affected. Similarly, products most subject to increasing European protectionism or to a very rapid growth in supply due to technological progress were also seriously harmed.

However, the crisis of 1929 rapidly worsened the terms of trade for South American agricultural exports, as happened on an international scale with the terms of trade for primary products compared to manufactures (Ocampo and Parra 2010). Excess supply in the agricultural product markets in a highly deflationary context profoundly depressed the prices of these products. Although throughout the decade a slight improvement situated the terms of trade at a similar level to that of the beginning of the century, the fall in relation to the pre-war maximum was notable.

It is important to emphasise that it is most reasonable to assume that the decline in the terms of trade was not compensated for by an improvement in agricultural productivity exceeding that of manufactures ${ }^{13}$.

In contrast to the First World War, the terms of trade improved modestly during the Second World War. The loss of the majority of South America's trade partners in continental Europe, the notable reduction of exports to the British market as a consequence of the submarine war, the priority awarded to military supplies in maritime transport and Britain's difficulties in purchasing imported goods due to its shortage of currency, meant that demand fell significantly. Only the North American market and that of Latin America itself resisted the problems of the war. However, the restricted needs of the United States and the limited degree of interregional trade (despite its substantial growth, since it multiplied several times in those years) could not compensate for the markets lost in Europe (Carreras-Marín et al. 2013) ${ }^{14}$.

The end of the war and the progressive normalisation of maritime transport improved South American terms of trade somewhat, which nevertheless continued to be anchored at the low levels of the interwar period. Peace, from the perspective of the behaviour of the relative prices of South American exports, did not therefore signify a significant change in trend. The opposite was in fact true, and reaffirmed the pessimistic perspective regarding the long-term evolution of the terms of trade, in a period in which this question was becoming one of the cornerstones of the approach of the structuralist school and particularly that of Raul Prebisch. Only the Korean War changed the situation, although very circumstantially. In 1950 and 1951, the intense demand for raw materials and food produced a very sharp, although fleeting, increase in prices and consequently a drastic

13 For the South American countries there is no comparison of the evolution of productivity by sector in the period analysed. If we take as reference the most technologically advanced country, the United States, between 1889 and 1929 the productivity of the farm sector increased by 30 per cent. The non-farm sector expanded in the same years by 144 per cent (Carter et al. 2003pp. 3/363-364).

14 Intraregional trade for the South American countries did not exceed 15 per cent of their total exports in their great expansion during the Second World War (Carreras-Marín et al. 2013). 
TABLE 6

TERMS OF TRADE FOR AGRICULTURAL AND FOOD PRODUCTS, 1900-1959 $(1924-1928=100)$

\begin{tabular}{|l|c|c|c|c|c|c|c|c|}
\hline & $\begin{array}{c}\mathbf{1 9 0 9 -} \\
\mathbf{1 9 1 3}\end{array}$ & $\begin{array}{c}\mathbf{1 9 2 4 -} \\
\mathbf{1 9 2 8}\end{array}$ & $\begin{array}{c}\mathbf{1 9 2 8 -} \\
\mathbf{1 9 3 2}\end{array}$ & $\begin{array}{c}\mathbf{1 9 3 4 -} \\
\mathbf{1 9 3 8}\end{array}$ & $\begin{array}{c}\mathbf{1 9 4 0 -} \\
\mathbf{1 9 4 4}\end{array}$ & $\begin{array}{c}\mathbf{1 9 4 5 -} \\
\mathbf{1 9 4 9}\end{array}$ & $\begin{array}{c}\mathbf{1 9 5 0 -} \\
\mathbf{1 9 5 4}\end{array}$ & $\begin{array}{c}\mathbf{1 9 5 5 -} \\
\mathbf{1 9 5 9}\end{array}$ \\
\hline Europe & 135 & 100 & 69 & 77 & 81 & 84 & 100 & 78 \\
\hline $\begin{array}{c}\text { North and } \\
\text { Central } \\
\text { America }\end{array}$ & 108 & 100 & 74 & 77 & 72 & 93 & 96 & 80 \\
\hline $\begin{array}{l}\text { South } \\
\text { America }\end{array}$ & 101 & 100 & 81 & 85 & 79 & 86 & 97 & 80 \\
\hline Asia & 198 & 100 & 54 & 59 & 64 & 60 & 75 & 66 \\
\hline Africa & 98 & 100 & 75 & 78 & 81 & 84 & 100 & 78 \\
\hline Oceania & 84 & 100 & 76 & 85 & 83 & 78 & 93 & 66 \\
\hline
\end{tabular}

Notes: We have used the Grilli-Yang prices deflated by an index of manufactured imports from industrialised countries. For each region, the index has been constructed taking into account the relative weight of each product in its agricultural exports in the years 1924-1928.

Sources: Authors' compilation, based on Pfaffenzeller et al. (2007) and IIA (1910-1939).

improvement in the terms of trade, although they did not even approach the highest levels of the first two decades of the century. In the remaining years of the 1950s, the terms of exchange for the Latin American countries slowly worsened, embarking upon a downward slope which would accelerate from 1973 until the end of the XX century (Serrano and Pinilla 2011b).

If comparison is made of the terms of trade in the years for which export averages are available, a stable trend can be observed between 1909-1913 and 1924-1928, followed by a significant subsequent fall, which by the end of the 1930s was $\sim 15$ per cent (Table 6).

Obviously, the behaviour of the nominal prices of the distinct agricultural products was highly varied, meaning that the impact on the terms of trade of agricultural exports in different countries varied depending on the composition of their exports (Table 2).

Meats were the products which behaved best, with regard to both the minimum of 1930-1931 and the pre-war maximum or the figure at the start of the century. In the British market, the world's principal importer of meat, the nominal wholesale prices of beef fell significantly, but by notably less than the general price index. Consequently, its real prices had increased substantially since the onset of the crisis, both in the case of British beef (by 18 per cent for top quality British beef in 1933 with regard to 1928, or by 27 per cent for top quality chilled Argentine beef) (Imperial Economic Committee 1934a, p. 310). 
TABLE 7

PURCHASING POWER OF AGRICULTURAL AND FOOD EXPORTS, 1900-1938 $(1924-1928=100)$

\begin{tabular}{|l|c|c|c|c|}
\hline & $\mathbf{1 9 0 9 - 1 9 1 3}$ & $\mathbf{1 9 2 4 - 1 9 2 8}$ & $\mathbf{1 9 2 8 - 1 9 3 2}$ & 1934-1938 \\
\hline Europe & 169 & 100 & 72 & 61 \\
\hline North and Central America & 69 & 100 & 65 & 50 \\
\hline South America & 68 & 100 & 83 & 88 \\
\hline Asia & 113 & 100 & 62 & 71 \\
\hline Africa & 65 & 100 & 88 & 111 \\
\hline Oceania & 61 & 100 & 91 & 115 \\
\hline
\end{tabular}

Notes: To calculate the purchasing power of exports, account is taken of the variation with regard to the base years (1924-1928) of both the volume of exports and the terms of trade. It therefore measures the purchasing power of manufactures with regard to the variation in the volume exported and to the variation in the relative prices of agricultural products in relation to such manufactures. The volume of exports has been calculated using 1925 prices.

Sources: Table 5 and Online Appendix, Table A.1.

For the remaining products crucial to South American agricultural exports, cereal prices behaved with moderation, while coffee fell substantially with respect to the pre-war maximum, although in relation to the beginning of the century its behaviour was better. The evolution of coffee prices responded not only to the dynamics of the market but also to the intervention from 1906 onwards of the Brazilian government and that of the state of Sao Paulo, employing policies of «valuation» which took advantage of its almost monopolistic position in the international market in an attempt to maintain prices, storing the product when prices fell. This explains the high coffee prices in the 1920s, and when these policies were ended in 1929 prices plummeted yet further. The exceptional harvests in the early 1930s and the collapse of prices obliged the Brazilian government to go so far as to destroy surplus harvests to avoid a total disintegration of prices, in addition to implementing other policies aimed at limiting supply (Bacon and Schloemer 1940).

As a result of this evolution of the terms of trade, the purchasing power of the agricultural exports of South America underwent a notable increase until the onset of the crisis of 1929. This was a consequence of the considerable expansion of the volume of exports, while prices remained relatively stable (Table 7). The crisis having begun, the fall was considerable, since the slight increase in export volume far from compensated for the deterioration in the terms of trade.

Despite everything, it may be said from an international perspective that this evolution was not excessively negative. Taking into account the level of 
TABLE 8

PURCHASING POWER OF AGRICULTURAL AND FOOD EXPORTS, 1951-1960 $(1951-1955=100)$

\begin{tabular}{|l|c|c|}
\hline & $\mathbf{1 9 5 1 - 1 9 5 5}$ & $\mathbf{1 9 5 6 - 1 9 6 0}$ \\
\hline Europe & 100 & 100 \\
\hline North and Central America & 100 & 151 \\
\hline South America & 100 & 75 \\
\hline Asia & 100 & 160 \\
\hline Africa & 100 & 163 \\
\hline Oceania & 100 & 79 \\
\hline
\end{tabular}

Notes: The volume of exports has been calculated using 1980 prices.

Sources: Table 5 and Online Appendix, Table A.4.

the terms of trade in the years 1924-1928, those of the agricultural exports of South America fell least (together with those of Oceania). It may therefore be concluded that the purchasing power of South American agricultural exports, despite slipping significantly as a consequence of the crisis, fell by less than the majority of the remaining exporters of primary products. Obviously, the results were better for countries such as Argentina or Uruguay, with a significant concentration on the export of beef (and cereals), than Brazil, strongly specialised in the export of coffee.

In summary, and as Díaz Alejandro (1988) has already signaled, for South American exporters during the recession the deterioration in the terms of trade was worse than the fall in volume, since the latter was recovered during the 1930s. Price falls did not mean a reduction in the volume of exports, but instead deliberate attempts to increase exports to compensate for such falls.

Obviously, the slow improvement in the terms of trade from 1939 on did not permit a substantial improvement in the purchasing power of exports, since their evolution in volume was also slow. Having embarked upon the volte-face in the model of development, the evolution of the purchasing power of South American exports deteriorated notably, in both volume and relative prices.

\section{CONCLUSIONS}

On the eve of the First World War, the South American countries accounted for a very significant part of international trade in agricultural products. The expansion of their exports in the preceding decades had been based on a formidable shifting of their frontiers, colonising land till then 
uncultivated and used by the original populations of the subcontinent. The arrival of emigrants and capital from Europe radically transformed the economies of the southern cone of South America, while their impact was far lower in countries such as Venezuela, Peru, Colombia, Ecuador or a large part of Brazil. In general, by 1914 export-led growth had generated an important process of economic development, above all in Argentina and Uruguay.

Whether these were countries in which the agroexporting model had generated very positive or only moderate results, all the economies of South America were highly dependent on international markets. Given this context, the potential for harm of the First World War did not materialise. Agricultural exports from South America recovered with notable success from the problems posed by the war, probably achieving their record figures between 1924 and 1928.

The crisis of 1929 affected the volume of these exports, which nevertheless reacted successfully to the problems posed by the destructive trade policies implemented by some of their principal trading partners. Thus, at the end of the 1930s the volume of agricultural exports from South America was slightly greater than before the crisis.

In a context as difficult as that of the interwar period, South America succeeded not only in maintaining its percentage by volume of world agricultural exports, but in slightly increasing it.

Agricultural exports from South America were initially highly concentrated in four product groups: cereals, meat, wool and coffee and cocoa (90 per cent of its total exports in 1909-1913). All these products were seriously affected by the fall in trade during the Depression. Exports of traditionally insignificant products such as cotton or oilseeds behaved much more dynamically.

The Second World War meant a new blow for South American exporters, who lost a considerable part of the European markets, whether due to the conflict itself and the occupation by Germany of a large part of the continent or to the British difficulties in maintaining its level of imports. The North American and interregional markets partially cushioned the damage produced. The post-war reconstruction maintained a highly protected international agricultural trade; South America maintained export levels substantially below those of the pre-war period. The about-face in the development model produced a collapse in export levels, precisely when international agricultural trade was starting to grow at an extraordinarily fast rhythm.

The fall in prices of agricultural exports from South America was important when the period is analysed as a whole. Its terms of trade increased very significantly until approximately 1921. The 1920s displayed highly irregular behaviour but a clear downward trend, and the terms of trade further deteriorated in the 1930s; by the end of that decade they were 15 per cent lower than those existing before 1929. This was the consequence of the principal damage the Depression caused the South American 
economies. The great effort they made to increase their volume of exports in such difficult times did not compensate for the falls in their relative prices. The Second World War did not substantially improve the terms of trade of South American agricultural exporters. The relative prices of agricultural products did not recover the levels before the Great Depression.

In summary, it can be stated that South American agricultural exporters were faced with a succession of important external shocks to their trade, which was essential for their economic growth. In general, they reacted dynamically until the Second World War and attempted to compensate for the deterioration of their terms of exchange by a greater volume of exports. Despite this, the instability of trade flows, the severity of the shocks and the decreasing trend of the terms of trade gave rise to a deep-seated pessimism regarding the possibilities of maintaining export-led growth. The impact of the Second World War on South American trade was very strong. At its end, from Latin America a highly pessimistic calculation was made of the possibilities of recovering the markets of the European continent, devastated by the conflict. It can be said, in summary, that the exporting countries of South America suffered a succession of problems from 1914 on which were sufficiently large to understand the export pessimism which spread throughout the region in the 1940s. All this was key for Raúl Prebisch, the principal economist of the new structuralist school, to propose that the Latin American countries abandon the agroexporting model and follow an inwardlooking development model $^{15}$.

\section{SUPPLEMENTARY MATERIAL}

To view supplementary material for this article, please visit http://dx.doi. org/10.1017/S0212610915000063.

\section{REFERENCES}

Albert, B. (1988): South America and the First World War. The Impact of the War on Brazil, Argentina, Peru and Chile. Cambridge: Cambridge University Press.

Aparicio, G., and Pinilla, V. (2015): «The Dynamics of International Trade in Cereals, 1900-1938», Working Paper SEHA, Sociedad Española de Historia Agraria.

Aparicio, G.; Pinilla, V., and Serrano, R. (2009): «Europe and the International Agricultural and Food Trade, 1870-2000», in P. Lains and V. Pinilla (eds), Agriculture and Economic Development in Europe Since 1870. London: Routledge, pp. 52-75.

Bacon, L. B., and Schloemer, F. C. (1940): World Trade in Agricultural Products. Its Growth; its Crisis; and the New Trade Policies. Rome: International Institute of Agriculture.

15 Díaz Alejandro (1975, p. 114) viewed the about-turn to a strategy of inward development in Argentina in 1943 as a late response to the Great Depression. 
Barsky, O., and Gelman, J. (2001): Historia del agro argentino. Desde la Conquista hasta fines del siglo XX. Buenos Aires: Grijalbo.

Brassley, P. (2012): «International Trade in Agricultural Products, 1935-1955», in P. Brassley, Y. Segers and L. VanMolle (eds), War, Agriculture, and Food: Rural Europe from the 1930s to the 1950s. London: Routledge, pp. 33-51.

Bértola, L., and Williamson, J. (2006): «Globalization in Latin America before 1940», in V. Bulmer-Thomas, J. H. Coatsworth and R. Cortés-Conde (eds), The Cambridge Economic History of Latin America, vol. II. The Long Twentieth Century. Cambridge: Cambridge University Press, pp. 11-56.

Bulmer-Thomas, V. (1994): The Economic History of Latin America Since Independence. Cambridge: Cambridge University Press.

Cadenazzi, G. (2012): «El Estancamiento del Agro Argentino y el Mercadomundial. De la Gran Depresión a la Segunda Guerra Mundial». Historia Agraria 57, pp. 79-104.

Cárdenas, E.; OcAmpo, J. A., and Thorp, R. (2000): «Introduction», in E. Cárdenas et al. (eds), An Economic History of Twentieth-Century Latin America. Vol. 3: Industrialization and the State in Latin America. The Postwar Years. New York: Palgrave, pp. 1-35.

Carreras-Marín, A., and Badia-Miró, M. (2008): "La Fiabilidad de la Asignación Geográfica en las Estadísticas de Comercio Exterior: América Latina y el Caribe (1908-1930)». Revista de Historia Económica-Journal of Iberian and Latin American Economic History 26 (3), pp. 355-373.

Carreras-Marín, A.; Badia-Miró, M., and Peres Cajías, J. (2013): «Intraregional Trade in South America, 1912-1950: The Cases of Argentina, Bolivia, Brazil, Chile and Peru». Economic History of Developing Regions 28 (2), pp. 1-26.

Carter, S. B., et al. (2003): Historical Statistics of the United States. Earliest Times to the Present, vol. 3. Cambridge: Cambridge University Press.

Commodity Research Bureau. (1939): The CRB Commodity Yearbook. New York: Commodity Research Bureau.

Cortés Conde, R. (1992): «El Crecimiento de la Economía Argentina, c. 1870-1914», in L. Bethell (ed.), Historia Económica de América Latina, vol. 10 América del Sur, c. 1870-1930. Barcelona: Cambridge UniversityPress/Editorial Crítica, pp. 13-40.

Díaz Alejandro, C. (1975): Ensayos sobre la historia económica argentina. Buenos Aires: Amorrortueditores.

Díaz Alejandro, C. (1988): "América Latina en los Años Treinta», in R. Thorp (ed.), América Latina en los años treinta. El papel de la periferia en la crisis mundial, México: Fondo de CulturaEconómica, pp. 31-68.

Empire Marketing Board. (1932): Meat. A Summary of Figures of Production and Trade Relating to Beef, Mutton and Lamb, Bacon and Hams, Pork, Cattle, Sheep, Pigs and Canned Meat. London: H.M. Stationery Office.

Federico, G. (2004): «The Growth of World Agricultural Production 1800-1938». Research in Economic History 22, pp. 125-182.

Findlay, R., and O’Rourke, K. H. (2007): Power and Plenty: Trade, War, and the World Economy in the Second Millennium. Princeton: Princeton University Press.

FitzGerald, E. V. K. (2000): «ECLA and the Theory of Import Substituting Industrialization in Latin America», in E. Cárdenas et al. (eds), An Economic History of TwentiethCentury Latin America. Vol. 3: Industrialization and the State in Latin America. The Postwar Years. New York: Palgrave, pp. 58-97.

Food and Agriculture Organization of the United Nations. (1947-2000): Trade Yearbook. Rome: FAO.

Francis, J. A. (2013): «The Terms of Trade and the Rise of Argentina in the Long Nineteenth Century». London School of Economics and Political Science, PhD dissertation. 
Grilli, E. R., and YANG, M. C. (1988): «Primary Commodity Prices, Manufactured Good Prices and the Terms of Trades of Developing countries: What the Long Run Shows». The World Bank Economic Review 2 (1), pp. 1-47.

Hora, R. (2012): «La Evolución del Sector Agroexportador Argentino en el Largo Plazo, 1880-2010». Historia Agraria 58, pp. 145-181.

HyNES, W.; JACKS, D. S., and O'RourKe, K. H. (2012): «Commodity Market Disintegration in the Interwar Period». European Review of Economic History 16 (2), 119-143.

Imperial Economic Committee. (1934a): Cattle and Beef Survey. A Summary of Production and Trade in the Empire and Foreign Countries. London: H.M. Stationery Office.

Imperial Economic Committee. (1934b): Reports of the Imperial Economic Committee, Twenty-Eighth Report, Maize. London: H.M. Stationery Office.

Institut International d'Agriculture et Bureau de la F.A.O. À Rome. (1947): Annuaire International de Statistique Agricola 1941-42 à 1945-46. Rome: Institut International d'Agriculture et Bureau de la F.A.O. à Rome.

International Institute of Agriculture. (1910-1939): International Yearbook of Agricultural Statistics. Rome: International Institute of Agriculture.

International Institute of Agriculture. (1936): International Trade in Meat. Rome: International Institute of Agriculture.

Llach, L. (2006): Argentina y el Mercado Mundial De Sus Productos. Buenos Aires: CEPAL.

Love, J. L. (1996): "Ideas and Ideologies in Twentieth Century Latin America», in L. Bethell (ed.), Ideas and Ideologies in Twentieth Century Latin America. Cambridge: Cambridge University Press, pp. 207-274.

Maddison, A. (2001): The World Economy. A Millennial Perspective. Paris: OECD.

Malenbaum, W. (1953): The World Wheat Economy, 1885-1939. Cambridge, MA: Harvard University Press.

Ocampo, J. A., and Parra-Lancourt, M. A. (2010): «The Terms of Trade for Commodities Since the Mid-19 ${ }^{\text {th }}$ Century». Revista de Historia Económica. Journal of Iberian and Latin American Economic History 28 (1), pp. 11-44.

O'Connell, A. (1988): «La Argentina en la Depresión: los Problemas de una Economía Abierta», in R. Thorp (ed.), América Latina en Los Años Treinta. El Papel de la Periferia en La Crisis Mundial. México: Fondo de Cultura Económica, pp. 217-259.

O'Connell, A. (2001): «The Return of «Vulnerability» and Raul Prebisch's Early Thinking on the «Argentine Business Cycle»». CEPAL Review 75, pp. 51-65.

Paiva Abreu, M. (1988): «La Argentina y Brasil en los Años Treinta. Efectos de la Política Económica Internacional Británica y Estadounidense», in R. Thorp (ed.), América Latina en los Años Treinta. El Papel de la Periferia en la Crisis Mundial. México: Fondo de Cultura Económica, pp. 171-190.

Paiva Abreu, M. (2006): «The External Context», in V. Bulmer-Thomas, J. H. Coatsworth and R. Cortés-Conde (eds), The Cambridge Economic History of Latin America, vol. II. The Long Twentieth Century. Cambridge: Cambridge University Press, pp. 101-134.

Pfaffenzeller, S.; Newbold, P., and Rayner, A. (2007): "A Short Note on Updating the Grilli and Yang Commodity Price Index». The World Bank Review 21 (1), pp. 151-163.

Pinilla, V., and Ayuda, M. I. (2002): «The Political Economy of the Wine Trade: Spanish Exports and the International Market, 1890-1935». European Review of Economic History 6 (1), 51-86.

Pinilla, V., and Ayuda, M. I. (2009): «Foreign Markets, Globalization and Agricultural Change in Spain, 1850-1935», in V. Pinilla (ed.), Markets and Agricultural Change in Europe from the $13^{\text {th }}$ to the $10^{\text {th }}$ century. Turnhout: Brepols Publishers, pp. 173-208. 
Pinilla, V., and Ayuda, M. I. (2010): «Taking Advantage of Globalization? Spain and the Building of the International Market in Mediterranean Horticultural Products, 1850-1935». European Review of Economic History 14 (2), pp. 239-274.

RAYEs, A. (2015): «La Estadística de las Exportaciones Argentinas, 1875-1913. Nuevas Evidencias e Interpretaciones». Investigaciones de Historia Económica - Economic History Research 11, pp. 31-42.

SalvuccI, R. (2006): "Export-Led Industrialization», in V. Bulmer-Thomas, J. H. Coatsworth and R. Cortés-Conde (eds), The Cambridge Economic History of Latin America, vol. II. The Long Twentieth Century. Cambridge: Cambridge University Press, pp. 249-292.

Serrano, R., and Pinilla, V. (2010): "Causes of World Trade Growth in Agricultural and Food Products, 1951-2000: A Demand Function Approach». Applied Economics 42 (27), pp. 3503-3518.

Serrano, R., and Pinilla, V. (2011a): «The Evolution and Changing Geographical Structure of World Agri-food Trade, 1950-2000». Revista de Historia Industrial 46, pp. 95-123.

Serrano, R., and Pinilla, V. (2011b): «Terms of Trade for Agricultural and Food Products, 1951-2000». Revista de Historia Económica - Journal of Iberian and Latin American Economic History 29 (2), pp. 213-243.

Serrano, R., and Pinilla, V. (forthcoming): "The Declining Role of Latin America in Global Agricultural Trade, 1963-2000». Journal of Latin American Studies.

TAYlor, A. E. (1928): «Rye in its Relation to Wheat». Wheat Studies IV (5), pp. 181-234.

Tena, A., and Willebald, H. (2013): "On the Accuracy of Export Growth in Argentina, 1870-1913». Economic History of Developing Regions 28 (1), pp. 28-68.

Wickizer, V. D. (1943): The World Coffee Economy, with Special Reference to Control Schemes. Stanford: Food Research Institute/Stanford University.

Williamson, J. G. (2008): «Gobalization and the Great Divergence: Terms of Trade Booms, Volatility and the Poor Periphery, 1782-1913». European Review of Economic History 12 (Part 3), pp. 355-392.

Yañez, C.; Rivero, R., Badia-Miró, M., and Carreras-Marín, A. (2014): «Nuevas Series Anuales de Población de América Latina Desde el Siglo XIX Hasta el 2000». Scripta Nova-Revista Electrónica de Geografía y Ciencias Sociales 18 (471), pp. 1-31. 